Jurnal IImu Komunikasi UHO : Jurnal Penelitian Kajian IImu Komunikasi dan Informasi.

Volume 6, No. 4, Oktober 2021, hlm 417-438

\title{
LITERASI DIGITAL DAN PANDEMI COVID-19: PERSEPSI MAHASISWA MENYIKAPI FENOMENA INFODEMIK
}

\author{
I Komang Agus Widiantara ${ }^{1}$, Niluh Wiwik Eka Putri $^{2}$, Ni Ketut Yuniati ${ }^{3}$ \\ Sekolah Tinggi Agama Hindu \\ (STAH) Negeri Mpu Kuturan Singaraja ${ }^{123}$ \\ J1 Pulau Menjangan No 27 Banyuning, Singaraja, Indonesia
}

\begin{abstract}
ABSTRAK
Luapan informasi atau infodemik Covid-19 melahirkan beragam berita hoaks dan menyesatkan bagi publik. Hal ini menjadi tantangan dalam literasi digital bagi para pengakses berita selama pandemi khususnya di kalangan terpelajar (mahasiswa). Penelitian ini mencoba untuk menggali referensi bermedia para mahasiswa di Program Studi Ilmu Komunikasi Sekolah Tinggi Agama Hindu (STAH) Negeri Mpu Kuturan Singaraja selama Pandemi Covid-19. Disamping itu juga untuk mengetahui persepsi dan tingkat literasi digital mahasiswa dalam merespon beragam informasi seputar infodemik Covid-19. Penelitian ini menggunakan metode kualitatif dengan pendekatan fenomenalogi. Teknik pengumpulan data dilakukan dengan wawancara, observasi, penelusuran bahan online, dan studi kepustakaan. Hasil penelitian menunjukkan media referensi mahasiswa selama pandemi yakni media sosial dan media mainstream. Beragam informasi seputar Covid-19 melahirkan persepsi mahasiswa diantaranya mahasiswa terjebak dalam pusaran konspirasi, rumor dan stigma; menilai pengobatan terhadap Covid-19 masih simpan siur; panik dan stres akibat infodemik; media mainstream dinilai memperkeruh situasi pandemi; sentimen negatif dengan aparat negara; pesimis kinerja Pemerintah tuntaskan Pandemi Covid-19; dan tumbuhnya semangat solidaritas sosial saat krisis. Kualitas literasi digital mahasiswa terbilang cukup baik dalam merespon infodemik Covid-19.
\end{abstract}

Kata Kunci : Literasi Digital, Covid-19, Infodemik 
Jurnal IImu Komunikasi UHO : Jurnal Penelitian Kajian IImu Komunikasi dan Informasi. Volume 6, No. 4, Oktober 2021, hlm 417-438

\begin{abstract}
The overflow of information or the Covid-19 infodemic gave birth to various hoax and misleading news for the public. This is a challenge in digital literacy for news accessors during the pandemic, especially among the educated (students). This study tries to find media references for students in the Communication Studies Program at the State Hindu High School (STAH) Mpu Kuturan Singaraja during the Covid-19 Pandemic. In addition, to find out the perception and level of student literacy in responding to various information about the Covid-19 infodemic. This study uses a qualitative method with a phenomenological approach. Data collection techniques were carried out by interviewing, observing, browsing online materials, and studying literature. The results showed that the student reference media during the pandemic were social media and mainstream media. Various information about Covid-19 gave rise to perceptions, including students being trapped in a vortex of conspiracy, rumors and stigma; assessment of treatment for Covid-19 is still unclear; panic and stress due to the infodemic; mainstream media is considered to have exacerbated the pandemic situation; negative sentiment with state apparatus; pessimistic about the Government's performance in completing the Covid-19 Pandemic; and the growing spirit of social solidarity in times of crisis. The quality of student digital literacy is quite good in responding to the Covid-19 infodemic.
\end{abstract}

Keyword: Digital Literacy, Covid-19, Infodemic 
Jurnal IImu Komunikasi UHO : Jurnal Penelitian Kajian IImu Komunikasi dan Informasi.

Volume 6, No. 4, Oktober 2021, hlm 417-438

\section{PENDAHULUAN}

Covid -19 menjadi tantangan terbesar media mainstream untuk memberikan informasi sehat bukan menyesatkan publik. Media arus utama belum bisa menahan laju informasi keliru dan bohong tentang virus Corona yang kian berkembang dan berbanding lurus dengan masifnya pemberitaannya. Hal ini menurut WHO sebagai pemicu lahirnya pandemi informasi yang kemudian dikenal dengan istilah infodemic.

Setidaknya ada 800 orang meninggal di seluruh dunia karena kesalahan informasi terkait Covid-19. Bahkan peristiwa ini terjadi hanya dalam tiga bulan pertama (kompas.id, 2020). Angka ini menunjukkan bahawa dampak dari informasi yang keliru dan menyesatkan yang bertebaran di media sosial terkesan lebih mengerikkan ketimbang dampak dari Covid19. Mengkonsumsi informasi berlebihan dengan akses media yang mudah menjadi fenomena sepanjang tahun 2020-2021. Termasuk Indonesia yang mengalami ihwal serupa. Maraknya berita hoaks tentang Covid-19 beserta beragam anjuran kesehatan menjadi narasi yang mudah diduplikan pesanya ke berbagai forum virtual yang berujung berujung viral.

Saiful Islam dari Program for Emerging Infections, Infectious Diseases Division, Bangladesh, dan peneliti di American Journal of Tropical Medicine and Hygiene (kompas.id) turut mengulas, selain 800 korban meninggal, dari hasil riset yang dilakukan sekitar 5.800 orang yang dirawat di rumah sakit akibat informasi palsu tentang penyembuhan Covid-19 di media sosial. Hasilnya ditemukan 2.311 infodemik Covid-19 tersebar 25 bahasa dari 87 negara di seluruh dunia dalam kurun waktu 21 Januari- 5 April 2020. Dari jumlah tersebut, 2.049 (89 \%) informasi yang berkembang di berbagai kanal media didominasi oleh narasi rumor. Selanjutnya $182(7,8 \%)$ teori konspirasi, dan 82 ( 3,5\%) stigma. Sementara kategori informasi ditemui $24 \%$ terkait penyakit, penularan, dan kematian. 21 \%terkait intervensi, $19 \%$ untuk pengobatan dan penyembuhan, $15 \%$ untuk penyebab penyakit termasuk asalnya, $1 \%$ kekerasan, dan $20 \%$ untuk lain-lain.

Ada 2.276 informasi yang ditemukan dengan rincian 1.856 (82\%) klaim salah, 204 (9\%) berbasis bukti, $176(8 \%)$ menyesatkan, dan 31 (1\%) tidak terbukti. Menariknya informasi yang berkembang dari pemetaan yang dilakukan dalam kajian tersebut sebagian besar dimoninasi oleh rumor, stigma, dan teori-tori konspirasi yang sebagian besar dari berbagai negara seperti India, Amerika Serikat, China, Spanyol, Indonesia, dan Brasil. Selama pandemi berlangsung klaim-kalim keliru seputar pengobatan Covid-19 banyak bermunculan. Baik yang bersifat tradisional maupun moderen. Klaim penyembuhan yang paling banyak menjadi perbincangan di kalangan warganet yakni mengkonsumsi alkohol 
Jurnal IImu Komunikasi UHO : Jurnal Penelitian Kajian Ilmu Komunikasi dan Informasi.

Volume 6, No. 4, Oktober 2021, hlm 417-438

dengan jumlah tinggi dengan alasan mampu melawan virus. Klaim lain juga tidak kalah semarak diperbincangkan seperti mengkonsumsi bawang putih, minum air seni sapi, berjemur hingga meminum disinfektan. Dari riset yang dilakukan tersebut bisa disimpulkan bahwa infodemik mengisi percakapan digital di ruang virtual adalah berita palsu.

Kominfo (2020) juga mengidentifikasi hal serupa terkait perkembangan berita hoaks dan disinformasi mencapai 1401 yang tersebar luas di ruang publik. Beredarnya informasi pandemi tidak hanya menyesatkan dan tidak dapat dipertanggungjawabkan, namun juga terkait dengan anggapan COVID-19 merupakan konspirasi dan hoaks. Sekjen WHO, Tedrom Adhanom Ghebreyesus, mengatakan saat ini umat manusia secara global tidak semata menghadapi epidemi namun yang tidak kalah membahayakan adalah infodemik dari sumber berita yang tidak kredibel dan berseliweran di ruang digital. Bahkan Lopez dan Martin (2020) menilai seharusnya perkembangan COVID-19 di US seharusnya tidak mencapai 20 persen, namuan nyatanya di lapangan duplikasi dan pabrikasi informasi tentang Covid-19 terjadi dengan luar biasa, seolah sulit untuk dibendung.

Harus diakui sumber informasi yang terlalu banyak dan sulit membedakan sumber kredibel oleh publik karena tingkat literasi bervariasi menjadi persoalan serius dalam menghadapi infodemik. Hal ini dipengaruhi pula, ketidaksingkoranan informasi yang diperoleh antara kebijakan Pemerintah Pusat dan Daerah yang seolah-olah bertolak belakang membuat publik mengalami kegamangan dalam memilah dan memilih informasi terkait Covid-19. Hal tersebut tercermin saat sejak awal Pandemi Covid-19 muncul di Indonesia, reaksi pengambil kebijakan tidak siap. Hal ini mempengaruhi komunikasi publik yang dilakukan belum maksimal.

Ireton dan Posetti (2018) menilai masyarakat digital saat ini tidak melakukan aktivitas cek fakta dan validasi sumber informasi. Warga digital lebih memilih mengkonsumsi berita secara instan, informasi yang diperoleh melalui jejaring sosial pertemanan dan mesin pencari. Padahal dengan melakukan validasi informasi, siapapun akan memperoleh informasi berkualitas yang menyehatkan dan menjauhkan publik dari narasi menyesatkan di ruang digital. Terlebih di masa pandemi saat ini, produktivitas mengakses informasi sangat besar. Frekuensi pengguna internet juga meningkat pesat selama pembatasan dilakukan oleh Pemerintah, termasuk di bidang pendidikan hingga ekonomi. Jika paparan informasi tidak kredibel, bisa dipastikan warganet akan menafsir dan bereaksi dengan cepat atas informasi yang dikonsumsi. Melawan segala bentuk infodemik Covid-19 tentu dibutuhkan tingkat literasi yang baik, mumpuni dan komprehenship. Lembaga pendidikan tinggi menjadi domain 
Jurnal IImu Komunikasi UHO : Jurnal Penelitian Kajian IImu Komunikasi dan Informasi.

Volume 6, No. 4, Oktober 2021, hlm 417-438

strategis dalam membangun budaya (culture) literasi. Kalangan cendikia dan terdidik di lembaga ini setidaknya lebih terbuka dan terorganisir pemikirannya mengenai berbagai pengetahun dan informasi, mana yang pantas dan layak untuk dikonsumsi. Mahasiswa sebagai agen perubahan (agent of change) menjadi pintu masuk pencerdasn literasi yang bisa dilakukan secara dinamis dengan pergulatan pemikiran yang bisa dikategorikan di atas ratarata. Daya nalar dan kritis civitas kampus menjadi jembatan yang sangat efektif dan efesien dalam membumikan literasi di tengah digitalisasi.

Hal tersebut sejalan untuk mempersiapkan generasi abad-21 yang wajib memiliki kompetensi literasi digital. Literasi digital tidak berhenti dalam konteks membaca, menulis dan berhitung atau sekadar penguasaan media digital secara teknis. Namun juga memiliki kreativitas untuk mampu memproduksi, kolaborasi, partisipasi dan membangun daya nalar yang kritis terkait pemanfaatan dan dampak yang ditimbulkan dari media digital. Disinilah agen perubahan seperti mahasiswa tampil sebagai poros tengah dan subjek kritis di tengah riuh rendahnya informasi digital yang kerap simpang siur. Mahasiswa dengan adaptasi tinggi dalam lautan informasi dan digitalisasi seharusnya bisa tampil sebagai agen intelektual yang memberikan rangsangan dan daya nalar rasional, tidak semata emosional menyikapi ragam informasi yang berseliweran di media sosial. Sudah seharusnya mahasiswa tampil sebagai aktor literasi digital. Hal ini sejalan dengan Paul Gilster dalam bukunya yang berjudul Digital Literacy (1997), literasi digital menuntut seseorang untuk mampu untuk memahami dan menggunakan informasi dalam berbagai bentuk dari berbagai sumber yang sangat luas yang diakses melalui piranti komputer. Dari latarbelakang di atas peneliti tertarik menggali sejauh mana kualitas literasi digital mahasiswa Program Studi Ilmu Komunikasi Sekolah Tinggi Agama Hindu (STAH) Negeri Mpu Kuturan Singaraja di tengah arus infodemik Covid-19. Ada tiga pertanyaan penting yang diuraikan dalam artikkel ini. Pertama, sumber media yang menjadi rujukan selama pandemi mahasiswa. Kedua,persepsi mahasiswa menyikapi infodemik Covid-19; Ketiga, sejauah mana pengaruh infodemik Covid-19 terhadap literasi digital mahasiswa.

Adapun literatur dan hasil penelitian sebagai perbandingan dalam tulisan ini mengacu pada isu-isu aktual Covid-19 yang telah berlangsung sejak 2020-2021. Fatmawati (2020) dalam penelitiannya Kompetensi Literasi Digital dalam Menangkal Infodemi mengkaji infodemik yang dapat menyebarkan misinformasi, disinformasi, mispersepsi, maupun rumor sehingga dibutuhkan kompetensi dalam literasi digital. Infodemik tidak hanya berhubungan dengan masifnya hoaks, tetapi juga dengan diseminasi 
Jurnal IImu Komunikasi UHO : Jurnal Penelitian Kajian IImu Komunikasi dan Informasi.

Volume 6, No. 4, Oktober 2021, hlm 417-438

informasi yang tidak sinkron. Untuk itu dibutuhkan tanggung jawab digital dan kerja sama semua pihak yang berwenang. Penelitian ini memliki hubungan dengan penulis lakukan terkait literasi digital. Hanya saja kajian dalam riset ini fokus kepada teoritik sementara peneliti lakukan fokus pada fenomenalogi dalam literasi mahasiswa di STAHN Mpu Kuturan Singaraja.

Irhandayaningsih (2020) dalam Pengukuran Literasi Digital Pada Peserta Pembelajaran Daring di Masa Pandemi COVID-19 menunjukkan responden memiliki tingkat literasi digital yang tinggi. Dalam literasi digital dasar pengguna internet mampu terhubung ke platform untuk mengikuti aktivitas digital. Mulai dari pembelajaran daring hingga aktivitas sosial di jejaring virtual. Penelitian ini memperkaya pengayaan terkait literasi digital mahasiswa. Perangin-angin (2021) dalam Infodemi di Ruang Komunitas Virtual: Aktualisasi Diri vs Akurasi menyoroti sikap pihak yang terakses media sosial untuk sesegera mungkin menyebarkan ulang informasi terbaru di ruang virtual karena rasa tanggung jawab sebagai anggota komunitas. Terlebih menganggap informasi tersebut penting untuk diketahui oleh anggota lainnya, walaupun tanpa mengecek ulang informasi tersebut terlebih dahulu ke situs resmi sebelum disebar-luaskan. Penelitian ini juga menguraikan kebutuhan personal untuk aktualisasi diri dan pengakuan secara sosial dalam komunitas virtual. Kajian ini relevan dengan penelitian yang penulis lakukan karena selain menganalisa respon selama infodemik sekaligus memotret perilaku mahasiswa Prodi Ilmu Komunikasi STAHN Mpu Kuturan Singaraja selama pandemi berlangsung.

Sutrisna (2020) dalam Gerakan Literasi Digital Pada Masa Pandemi Covid-19 berfokus pada konsep antisipasi berita hoaks pada masa pandemi covid-19. Ada beberapa strategi yang ditawarkan. Seperti meningkat jumlah dan variasi bahan bacaan literasi digital yang dimiliki setiap fasilitas publik khususnya dalam pencegahan covid-19; meningkatkan frekuensi membaca bahan bacaan literasi digital yang berkaitan dengan pencegahan covid-19; meningkan jumlah bahan bacaan literasi digital yang dibaca oleh masyarakat yang berkaitan dengan pencegahan covid-19; meningkan jumlah partisipasi aktif komunitas, lembaga atau instansi dalam penyediaan bahan bacaan literasi digital; meningkan jumlah fasilitas publik yang mendukung literasi digital; meningkatnya jumlah kegiatan literasi digital yang ada di masyarakat; partisipasi aktif masyarakat dalam kegiatan literasi digital; dan pemanfaatan media digital dan internet. Strategi dalam riset ini relevan dengan kajian yang dilakukan peneliti. 
Jurnal IImu Komunikasi UHO : Jurnal Penelitian Kajian IImu Komunikasi dan Informasi. Volume 6, No. 4, Oktober 2021, hlm 417-438

Gelgel, Ginting dan Apriani (2020) dalam Universitas Udayana Melawan Disinfodemic Melalui Kelas Literasi Antihoaks COVID-19 "Belajar Sembari Menyebar Berita Baik" memfokuskan peran Program Studi Ilmu Komunikasi Universitas Udayana (UNUD) melalui mata kuliah kajian media dan literasi melakukan berbagai upaya literasi dengan langsung mengidentifikasi informasi dan menyampaikan kepada masyarakat melalui media sosial mengenai kebenaran info seputar Covid-19. Mahasiswa dalam kajian tersebut memliki peran strategis dalam menyebarluaskan konten edukasi melalui media sosial dengan menggandeng MAFINDO (Masyarakat Anti Fitnah Indonesia). Berbeda halnya dengan peneliti lakukan yang memfokuskan pada respon mahasiswa atas infodemik. Meskipun demikian, pola literasi digital yang dilakukan dalam penelitian ini memiliki kemiripan dalam hal pemberdayaan mahasiswa.

Jumrana (2020) dalam Pemberdayaan Literasi Digital dalam Membangun Sistem Antihoaks menawarkan empat konsep penting menangani sistem hoaks diantaranya; prinsip, norma, dan nilai; hubungan antar pihak; dan eksistensi pemberdayaan itu sendiri. Sistem ini menggambarkan sinergi antara komunitas, pemerintah, media, dan pemangku kepentingan lainnya dalam membangun sistem antihoaks. Dalam sistem antihoaks, kerja sama dan kemitraan dibangun di atas nilai-nilai kesepahaman, kepedulian, kepercayaan, komitmen, dan motivasi yang sama untuk melawan hoaks serta meningkatkan literasi digital masyarakat. Sistem ini akan bekerja dengan baik bila melibatkan partisipasi semua pihak termasuk masyarakat.

Berbagai hasil penelitian terdahulu di atas tersebut masih berfokus pada respon mahasiswa sebagai bagian dari civitas akademika dalam pembelajaran daring karena Covid-19, peran mahasiswa dalam literasi digital hingga strategi pemberdayaan masyarakat dalam pusaran infodemik. Meski demikian penelitian juga memberikan sorotan atas upaya dan langkah strategis dalam menghadapi informasi hoaks yang berujung pada infodemik dari kalangan masyarakat luas. Penelitian di atas akan menjadi tumpuan untuk menelisik sejauh mana persepsi kritis mahasiswa merespon infodemik di tengah arus literasi digital yang mereka dapatkan dibangku perkuliahan khususnya mahasiswa Program Studi Ilmu Komunikasi STAHN Mpu Kuturan Singaraja.

Teori-teori yang digunakan dalam penelitian ini antara lain Teori Penggunaan dan Pemenuhan Kebutuhan (uses and gratifications ) yang berfokus terhadap audien. Teori ini mencoba menjelaskan tentang bagaimana audien memilih media yang mereka inginkan. Dimana audien atau khalayak yang secara aktif memilih dan memiliki kebutuhan serta 
Jurnal IImu Komunikasi UHO : Jurnal Penelitian Kajian IImu Komunikasi dan Informasi.

Volume 6, No. 4, Oktober 2021, hlm 417-438

keinginan yang berbeda-beda di dalam mengkonsumsi media. Audien di sini tentu para mahasiswa Program Studi Ilmu Komunikasi Sekolah Tinggi Agama Hindu (STAH) Negeri Mpu Kuturan Singaraja yang memiliki kebiasaan dan mengakses informasi dalam ruang digital. Sedangkan untuk mengetahui pengaruh informasi Covid-19 yang dinarasikan oleh pemerintah melaui komunikasi publik di berbagai media massa dan media sosial menggunakan pendekatan Teori Hegemoni dari Gramsci. Faktor utama yang mempengaruhi paradigma hegemoni dalam komunikasi massa adalah faktor ideologi dan politik karena keduanya dapat menciptakan, mempengaruhi, mengendalikan, membentuk pola pikir masyarakat. Termasuk infodemik Covid-19 yang menyeruak ke publik dengan cepat melalui hegemoni media dalam memborbardir ragam pesan bagi publik khususnya mahasiswa Prodi Ilmu Komunikasi STAHN Mpu Kuturan Singaraja. Hal tersebut akan memunculkan persepsi ideologis dan politik mahasiswa selaku pengakses media.

Sementara paradigma pendekatan stimulus respon terhadap infodemik Covid-19 mahasiswa Prodi Ilmu Komunikasi STHAN Mpu Kuturan Singaraja akan dicermati dari pengalaman mahasiswa secara langsung dalam melakukan berbagai aktivitas literasi digital, respon terhadap kebijakan pemerintah hingga aksi sosial sebagai bentuk dari empati kemanusiaan yang dibangun selama pandemi berlangsung.

\section{Metode Penelitian}

Metode penelitian yang digunakan dalam riset ini yakni pendekatan kualitatif. Menggunakan paradigma fenomenologi yang lebih diarahkan untuk memahami atau mempelajari pengalaman hidup manusia. Dengan demikian, fokus umum dari penelitian ini adalah untuk memeriksa dan meneliti esensi atau struktur pengalaman ke dalam kesadaran manusia (Tuffour: 2017). Secara prinsip, penelitian ini menganalisis dan mendeskripsikan pengalaman para mahasiswa Prodi Ilmu Komunikasi STAHN Mpu Kuturan mengenai infodemik Covid-19.

Penentuan informan dalan penelitian ini adalah purposive yakni para mahasiswa Prodi Ilmu Komunikasi STAHN Mpu Kuturan Singaraja dengan kriteria; 1) Aktif di media sosial sekaligus seorang konten kretor; 2) Aktivis kampus yang memiliki ketertarikan di bidang media dan digital seperti aktif di UKM Pers mahasiswa dan broadcasting; dan 3) aktif dalam berbagai kegiatan literasi digital

Pengumpulan data dilakukan melalui wawancara daring, observasi, penelusuran bahan online, dan studi kepustakaan. Wawancara sebagaimana yang lazim digunakan dalam 
Jurnal IImu Komunikasi UHO : Jurnal Penelitian Kajian IImu Komunikasi dan Informasi.

Volume 6, No. 4, Oktober 2021, hlm 417-438

penelitian kualitatif adalah teknik pengumpulan data primer yang diperoleh dari informan. Penelitian ini melakukan proses komunikasi dengan para informan yang dilakukan secara online melalui aplikasi Zoom Virtual. Wawancara dilakukan langsung kepada semua informan dari kalangan mahasiswa yang terdiri dari 7 orang.

Saat observasi, peneliti menggunakan catatan dan proses recording. Observasi dilakukan secara partisipatoris, peneliti turut bergabung dan melakukan aktivitas selayaknya objek pengamatan. Mengikuti perkembangan infodemik Covid-19 di berbagai forum media sosial maupun media mainstream. Termasuk terlibat langsung dalam kegiatan literasi digital sebagai proses edukasi mahasiswa di tengah pusaran informasi Hoaks. Untuk memperkuat fakta dan data mengenai trend Covid-19, peneliti juga memanfaatkan referensi secara digital melalui penelusuran literatur online dan studi kepustakaan yang relevan.

Analisis data dalam penelitian ini adalah Manual Data Analysis Procedure (MDAP) yang dilakukan sendiri oleh setiap peneliti sesuai dengan karakter metode kualitatif yang digunakan. Sedangkan tahapan desain penelitian yang digunakan melalui 6 tahap. Diantaranya, melakukan pengamatan, identifikasi dan re-check terhadap data, melakukan kategorisasi terhadap informasi yang diperoleh, menelusuri dan menjelaskan kategorisasi, menjelaskan hubungan-hubungan kategorisasi, menarik kesimpulan-kesimpulan umum dan membangun atau menjelaskan teori.

\section{HASIL DAN PEMBAHASAN}

Setiap hari media memberitakan informasi terbaru seputar Covid-19. Masyarakat sebagai konsumen media harus selektif dalam menerima kabar yang disampaikan oleh media. Jika tidak, maka informasi hoax yang akan diperoleh. Media sosial dan media mainstream menjadi sumber informasi popular masyarakat modern. Popularitas informasi tergantung intensitas dan durasi pesan yang tersampaikan dalam media tersebut. Mulai dari informasi yang sangat penting dan dibutuhkan masyarakat luas hingga informasi biasa. Menurut Van Dijk (2013) media sosial merupakan ruang untuk membangun eksistensi diri para penggunanya untuk melakukan aktivitas daring. Mulai dari merespon isu, membagikan hingga menyukai konten. Sehingga media online dinilai sebagai ruang atau fasilitator 
Jurnal IImu Komunikasi UHO : Jurnal Penelitian Kajian IImu Komunikasi dan Informasi.

Volume 6, No. 4, Oktober 2021, hlm 417-438

warganet saat ini untuk melakukan aktivitas komunikasi seperti halnya di dunia nyata. Hal ini pula yang cukup efektif membangun korelasi sebagai mahluk sosial. Meike dan Young (2012), mengartikan media sosial sebagai konvergensi antara komunikasi personal dalam arti saling berbagi di antara individu (to be shared one to one) dan media publik untuk berbagi kepada siapa saja tanpa ada kekhususan individu. Dalam artian tidak ada batasan privasi dalam ruang interaksi virtual yang dibangun oleh para penggunanya.

\section{Media Sosial dan Media Mainstream Menjadi Sumber Informasi}

Media Sosial dan media mainstream menjadi rujukan informasi selama Covid-19 bagi para mahasiswa di prodi Ilmu Komunikasi STAHN Mpu Kuturan Singaraja. Hal tersebut tercermin dari pandangan para mahasiswa yang diwawancarai selaku informan. Media sosial memiliki karakteristik tidak jauh berbeda dengan media siber (cyber) dikarenakan media sosial merupakan salah satu platform yang digandrungi oleh warganet saat ini baik dalam kemudahan mengakses maupun fitur-fitur komunikasi yang menarik bagi user.

Meskipun informsi melimpah mengenai Covid-19 ada di media sosial, para mahasiswa juga mengakses media mainstream yang dipercaya memiliki kredibilitas. Disamping itu masih ada anggapan media mainstream di dalam memberikan informasi, khususnya mengenai Covid-19 memiliki akurasi, profesionalitas, objektif dan ampuh dalam meminimalisir berita hoaxs.

"Saya biasanya mengakses media mainstream seperti televisi, dan media sosial, seperti instagram, twitter, facebook, tiktok, dan lain sebagainya, Saya memilih media sosial karena memberikan informasi secara cepat kepada masyarakat, terutama kalangan muda. Sedangkan saya tetap mengakses media mainstream karena lebih terpercaya dan biasanya informasinya sangat cepat dan terupdate" (Wawancara Adyelia Murti, 8 Juli 2021).

Motif mengakses media sosial dan media mainstream adalah untuk mencari informasi, menemukan model perilaku, memperoleh keadaan orang lain dan bersantai. Hal tersebut bisa dilihat dari informasi yang dicari mengenai Covid 19 yang masih selalu dibahas oleh media massa di Indonesia. Selain itu, terkait model perilaku, Mahasiswa Prodi Ilmu Komunikasi STAHN Mpu Kuturan Singaraja juga ingin melihat bagaimana perilaku antisipasi agar tidak terpapar virus Covid 19, belajar empati dengan informasi terkait pembagian sembako secara sukarela, dan bersantai dengan mengkonsumsi informasi positif dari media agar imun tetap terjaga dengan baik. 
Jurnal IImu Komunikasi UHO : Jurnal Penelitian Kajian IImu Komunikasi dan Informasi.

Volume 6, No. 4, Oktober 2021, hlm 417-438

"Menurut saya media kini sedang sakit. Tak hanya media sosial saja, namun tak jarang media mainstream juga bisa mengalami degradasi kredibilitas. Hal ini disebabkan adanya oknum yang tidak bertanggung jawab sehingga menggiring opini yang berujung sensasi serta memicu kericuhan massal. Maka dari itu, sifat dari kedua media ini saya nyatakan fleksibel, tergantung dari keakuratan media. Namun jika ditelisik, media mainstream jika melakukan kesalahan pun akan dikoreksi dulu oleh dewan pers. Maka, menurut saya media mainstream lebih bisa dipercaya" (Wawancara Aiswarya, 8 Juli 2021)

Pendapat para mahasiswa di atas memberikan gambaran selaku informan dalam penelitian ini dalam menggunakan dan mengakses informasi di media sosial maupun media mainstream selama pandemi Covid-19 dapat disimpulkan bahwa dari motif-motif mengakses media sosial maupun media mainstream mencerminkan pola kebutuhan mahasiswa Prodi Ilmu Komunikasi STAHN Mpu Kuturan Singaraja dalam mengakses informasi selama pandemi Covid-19. Mahasiswa memiliki tipologi bermedia yang hampir sama yakni lebih cenderung mengkonsumsi media sosial sebagai rujukan dalam mengetahui perkembangan aktual pandemi. Mengacu pada teori Uses and Gratification bagaimana audien menentukan pilihan media yang mereka inginkan. Khalayak dalam hal ini mahasiswa secara aktif memilih dan memiliki kebutuhan serta keinginan yang berbeda-beda dalam mengkonsumsi media. Tujuannya tidak lain untuk memenuhi rasa keingintahuan atas isu-isu aktual Covid-19 yang menjadi sorotan masyarakat luas. Motif mahasiswa Prodi Ilmu Komunikasi STAHN Mpu Kuturan Singaraja jika mengacu pada McQuail (2004:98) sebenarnya untuk mengakses informasi terkini yang ramai diperbincangkan publik, identitas pribadi dengan melakukan aktivitas berbagi informasi atau social proof, menikmati beragam fitur hiburan yang disajikan oleh media.

Ashadi Siregar dan Sondang Pasaribu (2001:57) menguraikan tiga jenis motif yang memicu seseorang untuk menggunakan media sebagai pemuasan informasi. Pertama, motif informasional. Tujuannya tidak lain untuk memperoleh uraian, penjelasan dan informasi utuh terkait informasi yang diinginkan. Dalam konteks ini, mahasiswa menginginkan informasi terkait Covid-19. Kedua, motif edukasional. Media yang diakses oleh publik tidak semata untuk mencari informasi. Melainkan mencari makna atau nilai yang terkandung dalam peranperan edukasi dari sebuah media itu sendiri. Ketiga, motif hiburan. Motif ini sangat penting disajikan oleh media. Pasalnya, publik atau khalayak membutuhkan pemenuhan psikologis berupa kesenangan yang menghibur di tengah berbagai informasi yang beragam disajikan media massa. Motif-motif bermedia di atas sebenarnya juga mencerminkan kondisi prilaku 
Jurnal IImu Komunikasi UHO : Jurnal Penelitian Kajian IImu Komunikasi dan Informasi.

Volume 6, No. 4, Oktober 2021, hlm 417-438

mahasiswa prodi Ilmu Komunikasi STAHN Mpu Kuturan Singaraja dalam mengakses informasi selama pandemi. Mahasiswa selain menggunakan media sosial juga mengakses media massa sebagai saluran informasi dalam memilih pesan sesuai dengan kebutuhannya baik mengirim, menerima dan menyimpan pesan.

\section{Persepsi Mahasiswa Menyikapi Infodemik Covid-19}

Covid-19 melahirkan dualitas persepsi publik. Ada yang mempercayai keberadaan virus tersebut di satu sisi abai dan lebih percaya dengan teori konspirasi yang menganggap bahwa perkembangan pandemi ini tak lebihnya hanya sekadar ladang bisnis bagi elit global dengan dalih-dalih rasional yang memantik emosional publik di media sosial. Bahkan konspirasi yang berkembang terkait Covid-19 seolah-seolah di-endorse oleh para tokoh dan public figure yang seharusnya memberikan edukasi sebagai tanggungjawab moril. Karena segala sikap, tindakan dan pikirannya rentan diduplikasi atau menajdi role model.

Selain publik secara luas, para intelektual kampus seperti mahasiswa turut mewarnai narasi dan percakapan publik mengenai sentimen pandemi yang memasuki tahun kedua ini. Dari wawancara dan pengamatan yang dilakukan peneliti, ada tujuh persepsi yang bisa disaripatikan dari pandangan atau gagasan mahasiswa di Program Studi Ilmu Komunikasi STAHN Mpu Kuturan Singaraja dalam merespon Pandemi Covid-19. Pertama, mahasiswa terjebak dalam pusaran konspirasi, rumor dan stigma. Awal kemunculan Covid-19 direspon dingin oleh berbagai lapisan masyarakat bahkan berbagai berita keliru yang tersebar luas di media sosial dikonsumsi tanpa mengaktifkan daya nalar. Tidak terkecuali para mahasiswa Program Studi Imu Komunikasi STAHN Mpu Kuturan Singaraja. Dari wawancara peneliti, kemunculan pandemi ini diawal juga diliputi ketidakpercayaan atas penyebaran dan dampak mematikan Covid-19. Hal tersebut dinilai hanya sekadar agenda setting media yang mendramatisir penyebaran Covid-19 di Wuhan, China dan kepentingan kapitalis serta elit global yang bertujuan melanggenggkan bisnis vaksin di masa depan.

Pada akhirnya pernyataan-pernyataan yang bertebaran di media sosial dipercaya dengan mudah ditambah lagi pesan atas ketidakpercayaan terhadap virus tersebut disuarakan lantang oleh berbagai public figur hingga influenzer di media sosial. Mahasiswa Prodi Ilmu Komunikasi Semester VI STAHN Mpu Kuturan singaraja menilai media massa terlalu berlebihan mempublikasikan keberadaan pandemi yang muncul di China tersebut. Ia tidak mempercayai sepenuhnya kabar dari media karena kondisi geografis berbeda dengan di 
Jurnal IImu Komunikasi UHO : Jurnal Penelitian Kajian IImu Komunikasi dan Informasi.

Volume 6, No. 4, Oktober 2021, hlm 417-438

China. Media mainstream dalam kaca mata mahasiswa terlalu mengekploitasi pemberitaan yang belum tentu kebenarannya.

"Diawal saya setuju dengan pernyataan para tokoh atau pihak yang menyatakan bahwa Covid-19 itu tidak seperti yang diberitakan di berbagai media. Saya rasa, ekploitasi pemberitaan tentang pandemi ini berlebihan. Itu hanya akal-akalnnya China untuk jual obat dan vaksin. Jujur saja saya muak banget dengan pemberitaan Covid ini. Yang menakut bukan virusnya, tapi beritanya. Saya juga berfikiran, jangan-jangan ini hanya persepsi kita saja yang dibangun oleh media sehingga membuat imun kita lemah. Karena setiap hari kita mengkonsumsi beritanya." (Dewi, Wawancara16 Juli 2021)

Pernyataan Dewi di atas sebenarnya menggambarkan opini publik pada umumnya di saat pandemi muncul di Indonesia. Di tengah minimnya informasi dan literasi mengenai Covid-19, media mainstream hanya meliput berdasarkan fakta di lapangan. Fakta-fakta yang dikumpulkan pun berdasarkan pemberitaan-pemberitaan media asing dan selebihnya menarasikan viralitas informasi korban yang berjatuhan di Wuhan, China yang diduga pandemi Covid-19 di media sosial.

Kedua, simpang siur pengobatan terhadap Covid-19. Sejak pandemi virus corona mencuat dan ramai diperbincangkan di media sosial hingga saat ini, banyak informasi yang beredar luas tentang anjuran mengkonsumsi obat-obatan atau melakukan aktivitas tertentu sehingga mampu menyembuhkan Covid-19. Salah satunya informasi keliru yang banyak beredar soal klaim obat Covid-19. Tidak sulit dijumpai di berbagai forum media sosial atau grup WhatsApp (WA). Klaim obat untuk membunuh virus corona dibungkus dengan beragam kesaksian dari pasien Covid-19 hingga ada pula klaim obat yang mengatasnamakan dokter yang divideokan hingga viral. Beredarnya informasi seputar Covid juga diakui oleh mahasiswa program Studi Ilmu Komunikasi di lingkungan STAHN Mpu Kuturan Singaraja menjadi sorotan. Mahasiswa mempersepsikan bahwa informasi pengobatan penyembuhan Covid-19 yang beredar luas di forum media sosial sangat meyakinkan sebab proses hingga langkah-langkah pengobatannya sangat meyakinkan. Ditambah lagi informasi hoaks dan narasi pemberitaan setiap hari yang mewartakan perkembangan Covid-19 tiada henti dengan korban yang terus berjatuhan, sehingga luapan informasi tersebut meneror publik. Hal inilah yang dinilai mahasiswa menjadi ruang kosong bagi para aktor hoax untuk menyebarkan ketakutan.

Ketiga, panik dan stres akibat infodemik. Masyarakat di berbagai lapisan mengalami gejala psikologi yang luar biasa selama pandemi. Informasi simpang siur tentang Covid-19 memperparah persepsi publik mengenai penanganannya. Pembatasan-pembatasan 
Jurnal IImu Komunikasi UHO : Jurnal Penelitian Kajian IImu Komunikasi dan Informasi.

Volume 6, No. 4, Oktober 2021, hlm 417-438

dalam skala mikro hingga besar di berbagai kota dilakukan oleh Pemerintah dalam mengantisipasi ruang gerak masyarakat dalam menekan penuluran menambah daftar panjang tingkat kepanikan warga. Kehawatiran yang mencekam akan pandemi menimbulkan depresi luar biasa masyarakat yang diekpresikan dalam berbagai gerakan dan perlawanan. (https://www.surveymeter.org/id/node/576)

Mahasiswa Program Studi Ilmu Komunikasi STAHN Mpu Kuturan Singaraja sebagai bagian dari elemen masyarakat juga mengalami hal serupa. Mereka mengalami depresi dan stress karea pola pembelaran sepenuhnya dilakukan secara daring. Ruang gerak kemahasiswaan yang terbatas membuat proses pembelajaran kurang maksimal di kampus. Komunikasi dan interaksi dalam lingkungan kampus adalah denyut nadi kampus dan mahasiswa. Bisa dibayangkan saat mereka harus mengurung diri dirumah untuk mengikuti praktik pembelajaran secara maraton digelar secara online. Upaya untuk menjauhkan diri dari kepanikan dan stres dilakukan oleh mahasiswa . Dengan melakukan berbagai kegiatan sosial organsiasi meskipun dengan jumlah terbatas, terlibat dalam berbagai event daring, aktif membuat konten-konten kreatif di media sosial hingga mengikuti berbagai kegiatan penunjang perkuliahan seperti kelas dan webinar secara online.

Keempat, media mainstream memperkeruh situasi pandemi. Media arus utama (media mainstream) yang memiliki tingkat kepercayaan tinggi selama ini oleh publik juga larut dalam narasi pemberitaan sensasional dan menakuti publik. Hal ini bisa publik rasakan di awal pandemi tahun 2020. Terutama media online yang tidak sekadar menyebarkan informasi namun juga memancing para pembacanya dengan judul-judul pemberitaan clikcbait terkait Covid-19. Dramatisasi pemberitaan penyebaran virus ini tidak jauh berbeda teroris yang mencari mangsa, sangat mencekam. Laporan media yang menyampaikan informasi ke publik tentang ketidakpastian dalam menghadapi pandemi memantik dan menumbuhkan rasa takut yang berlebihan. Meski berita tidak selalu memberitahu kita apa yang harus dipikirkan, tapi berita memberi tahu kita untuk berpikir mengenai apa (Jorgensen, 2020).

"Masyarakat sudah masa bodo. Saking banyaknya berita tentang Corona di media. Apalagi kondisi ekonomi dan kebutuhan masyarakat saat ini lebih penting. Daya kritis menurun. Mau hoax atau tidak, dalam pikiran kebanyakan orang saat ini tidak penting dan ngaruh, asalkan bisa makan hari ini. Jadi, ini PR (Pekerjaan Rumah) besar media mainstream untuk mengedukasi sebagai tanggungjjawab moril." (Novi, Wawancara 16 Juli 2021) 
Jurnal IImu Komunikasi UHO : Jurnal Penelitian Kajian IImu Komunikasi dan Informasi.

Volume 6, No. 4, Oktober 2021, hlm 417-438

Kelima, sentimen negatif dengan aparat negara. Sejak Pemberlakuan Pembatasan Kegiatan Masyarakat (PPKM) Darurat di Pulau Jawa-Bali reaksi masyarakat beragam. Kebijakan yang bertujuan meminimalkan angka persebaran Covid-19 ini diharapkan menekan penyebaran virus dan kematian. Tidak sekadar memberlakukan PPKM Darurat, Pemerintah juga serius melakukan sanksi tegas bagi para pelanggar PPKM Darurat. Tujuan pemberian sanksi agar PPKM Darurat ditaati seluruh elemen masyarakat. Namun penerapan kebijakan ini di lapangan menyisakan persoalan sosial dan persiteganan antara warga dan aparat negara yang bertugas. Imbas dari PPKM Darurat menuntut aktivitas masyarakat lumpuh terutama kegiatan ekonomi yang mengakibatkan mobilitas dan kerumunan orang. Para aparat baik dari kepolisian hingga Sat Pol PP harus terjun ke lapangan melakukan sweeping ke berbagai rumah makan, gedung atau perkatoran untk memberikan peringatan hingga teguran. Semua itu mengalami perlawanan dari masyarakat atas nama ekonomi.

Persepsi negatif terhadap kinerja aparat dalam menjalankan tigas selama PPKM darurat menjadi perhatian mahasiswa Ilmu Komunikasi STAHN Mpu Kuturan Singaraja. Atas pemberitaan mengenai pandemi yang berimbas pada para pedagang di tingkat lokal. Selain menyulitkan para pedagang khususnya para penjaja kuliner, para mahasiswa juga mengakui sulitnya mencari kebutuhan konsumsi di saat malam hari. Mengingat pusat-pusat perbelanjaan hingga warung makan harus tutup pada pukul 20.00. Hal ini diperparah juga dengan para oknum aparat yang melakukan pendekatan ke masyarakat dengan cara beringas dan kurang manusiawi saat penertiban ataupun mengurai kerumunan.

Keenam, pesimis kinerja Pemerintah tuntaskan Pandemi Covid-19. Para cendikia kampus yakni para mahasiswa yang mencermati pola dan kerja Pemerintah belum menunjukkan hasil yang memuaskan dalam penanganan Covid-19. Upaya pembatasan aktivitas masyarakat yang dilakukan oleh Pemerintah secara signifikan belum menunjukkan trend pandemi menurun, malah sebaliknya. Muncul kluster-kluster baru seiring aktivitas sosial kemasyarakatan yang tidak terkendali di lapangan. Di sisi lain, negara dalam menjamin keselamatan dan pemenuhan kebutuhan selama PPKM Darurat masih dipertanyakan, termasuk-bantuan-bantuan yang dilakukan belum menyasar secara efektif seluruh elemen masyarakat. (Wawancara Ganies, 16 Juli 2020)

Di sisi lain mahasiswa juga menilai penanganan Covid-19 sejauh ini tidak berjalan efektif karena tidak adanya kerjasama yang baik antara Pemerintah dan masyarakat, begitupun sebaliknya. Berkaca dari kondisi di lapangan, aturan Pemerintah yang sangat ideal 
Jurnal IImu Komunikasi UHO : Jurnal Penelitian Kajian IImu Komunikasi dan Informasi.

Volume 6, No. 4, Oktober 2021, hlm 417-438

dalam menekan laju Pandemi tidak sejalan dengan upaya dalam mencukupi kebutuhan pokok masyarakat untuk survive karena tuntutan agar tetap di rumah. Pemerintah dinilai tidak mendengar suara rakyat. Suara yang seharusnya di dengar sebagai bagian dari warga negara. Sehingg inilah yang memunculkan sikap apatisme terhadap berbagai aturan pemerintah.

Ketujuh, tumbuhnya semangat solidaritas sosial saat krisis. Aksi charity yang digelar oleh mahasiswa mampu berkolaborasi dengan civitas kampus dan pihak luar kampus merupakan aksi nyata yang dilakukan oleh mahasiswa Prodi Ilmu Komunikasi STAHN Mpu Kuturan sebagai bagian dari spirit solidaritas sosial. Dengan membagikan sembako kepada warga yang membutuhkan, masker hingga menggalang pendanaan yang digerakkan secara kolektif khususnya saat pemberlakukan PPKM Darurat. Gerakan-gerakan kolektif yang digagas diinternal kampus ini merupakan bukti bahwa intelektual kampus tidak semata berpangku tangan dan mengumpat dalam kegelapan menyikapi dampak pandemi, melainkan melakukan langkah kongkret dan menyalakan lilin kecil untuk menumbuhkan optimisme di masa krisis.

\section{Pengaruh Infodemik dan Literasi Digital Mahasiswa}

Kementerian Komunikasi dan Informatika (Kominfo) merilis data 1.733 hoaks terkait Covid-19 dan vaksin hingga Maret 2021. Data tersebut menajdi refleksi sebaran berita bohong di ruang digital yang mulai tidak sehat selama pandemi Covid-19. Infodemik mengenai pandemi secara langsung atau tidak langsung telah mengubah pemahaman, persepsi dan tindakan setiap orang yang memiliki akses ke media online atau media massa. Hal ini tidak terlepas dari pengaruh dan dominasi narasi yang menyesatkan dari media tersebut. Hegemoni menurut Gramsci bisa dimaknai sebagai kemampuan untuk mempengaruhi dalam menciptakan narasi tertentu dalam rangka mendominasi pikiran dan tindakan seseorang. Media dipandang mendominasi percapakan dan narasi masyarakat dunia saat ini. Bahkan dalam sebuah negara, peran media dimanfaatkan oleh pemerintah untuk agenda tertentu.

Wacana melalui media disebarluaskan dan berusaha untuk merasuki ideologi dan benak masyarakat sehingga menjadi pemahaman bersama. Praktik hegemoni berlaku juga di media sosial yang kini banyak digunakan masyarakat dalam mengakses informasi Covid-19. Narasi dan berbagai isu seputar pandemi telah menyita energi warganet dan publik. Dominasi media sosial yang terkadang mendikte kehidupan sosial masyarakat saat ini memiliki akses negatif. Terlebih di tengah kondisi kesehatan dan ekonomi masyarakat yang kian memburuk, 
Jurnal IImu Komunikasi UHO : Jurnal Penelitian Kajian IImu Komunikasi dan Informasi.

Volume 6, No. 4, Oktober 2021, hlm 417-438

Namun upaya dan gerakan melawan informasi hoax yang menghegemoni juga terus digencarkan oleh berbagai komunitas, kelompok masyarakat hingga lembaga pendidikan. Tujuannya tidak lain agar publik tidak terseret dalam rimba infodemik yang memliki dampak buruk. Peneliti memotret kondisi literasi di kalangan mahasiswa Prodi Ilmu Komunikasi STAHN Mpu Kuturan Singaraja dengan menggunakan aspek Spires dan Bartlett (2012) yakni melalui tiga tahapan diantaranya pencarian informasi, produksi informasi, dan mengomunikasikan konten atau informasi yang diperoleh.

Aspek yang pertama dari literasi digital menurut konsep Spires dan Bartlet adalah locating and consuming digital content (mencari dan mengonsumsi konten digital). Dalam konsep Spires dan Bartlet untuk aspek mencari dan mengonsumsi konten digital, mahasiswa prodi Ilmu Komunikasi STAHN Mpu Kuturan Singaraja sudah mampu memiliki nalar kritis terkait informasi terkait Pandemi. Hal tersebut bisa dicermati dari pernyataan Putu Juli sebagai berikut:

"Dengan adanya pandemic ini media sangat gencar dicari oleh masyarakat terkait covid 19, karena masyarakat sangat ingin tahu perkembangan terkait virus ini, maupun terkait informasi dari Pemeintah. Secara garis besar saya rasa banyak masyarakat yang percaya terhadp info-info yang beredar di sosial media terkait dengan virus ini, baik dampak, cara penangan maupun usaha-usaha untuk mencegah virus Covid-19. Pada intinya terkait dengan infodemik ini kita harus berhati hati dengan danya berita atau informasi yang kita terima, karna tidak semua berita tersebut benar adanya." (wawancara 21 Juli 2021)

Pernyataan Juli diatas setidaknya memberikan gambaran bahwa mahasiswa tidak serta merta terbawa arus informasi hoax. Meskipun harus diakui, infodemik mengenai Covid19 terkadang sulit dibedakan antar informasi yang betul-betul rekayasa atau sesuai dengan fakta di lapangan. Kedua, aspek kedua adalah creating digital content (membuat konten digital). Dari pengamatan dan pernyataan para mahasiswa, dalam konteks konten memang sebagian besar dari mereka sangat selektif dalam mereproduksi konten informasi terkait Pandemi. Mengingat tidak semua informasi mengenai Covid-19 bisa disebarluaskan. Ragam konten Covid-19, mahasiswa aktif melakukan edukasi mengenai pademi dalam beragam karya seperti imbauan dalam bentuk naratif hingga keterlibatan dalam lomba literasi yang menyangkut Pandemi. Ketiga, aspek lcommunicating digital content (mengomunikasikan konten digital). Mahasiswa melakukan berbagai validasi pemberitaan sehingga betul-betul konten atau informasi yang disebarluaskan tidak berdampak buruk bagi pengguna media lainnya. Hal itu pun yang dilakukan oleh Juli mahasiswa semester IV Prodi Ilmu Komunikasi. 
Jurnal IImu Komunikasi UHO : Jurnal Penelitian Kajian IImu Komunikasi dan Informasi.

Volume 6, No. 4, Oktober 2021, hlm 417-438

Ia mengatakan sangat hati-hati sekali dalam membagikan pemberitaan mengenai pandemi yang ia peroleh dari media mainstream maupun dari media sosial.

"Saya mencari informasi di google, situs kompasiana dan CNN. Ketika ada beberapa link berita yang namanya cukup aneh saya akan mengkonfirmasi lagi atau mencari lagi laman-laman web yang terpercaya. Untuk di media sosial yang mengikuti informasi melalui instragram khususnya akun-akun publik terpercaya atau akun Pemerintahan yang saya rasa berita hoak itu tidak ada." (Wawancara 20 Juli 2021)

\section{Pemberdayaan Mahasiswa Membangun Antihoak}

Gerakan antihoak merupakan sebuah gerakan sosial yang mempunyai empat aksi, yaitu kampanye, kontra narasi, advokasi, dan edukasi. Gerakan sosial bertujuan untuk menciptakan perubahan sosial (Wood \& Jackson, 1982; Killian dalam Sztompka, 2008). Gerakan mtersebut memiliki agenda untuk meningkatkan daya kritis masyarakat yang linier dengan pemikiran dan sikap sehingga tidak mudah terjebak dalam pusaran informasi hoaks. Gerakan antihoaks pula memiliki tujuan untuk melawan hegemoni buruk media massa dan media sosial yang mengabarkan Covid-19 dengan ekploitatif, dramatis dan berseri di layar kaca dan timeline media sosial. Hegemoni media sudah menajdi candu bagi publik yang ingin mengakses informasi dan memiliki naluri tinggi untuk melek mengenai kabar Covid-19.

Dalam konteks pemberdayaan literasi untuk membentuk sistem hoaks di lingkungan STAHN Mpu Kuturan Singaraja, para dosen di lingkungan Prodi Ilmu Komunikasi melakukan berbagai kegiatan untuk pemberdyaaan literasi bagi mahasiswa. Mulai dari webinar literasi digital dengan melibatkan mahasiswa dan para dosen ilmu komunikasi sebagai narasumber serta menggandeng narasumber kompeten lainnya dalam gerakan literasi nasional yang dicanangkan oleh pemerintah yang digelar secara berseri. Disamping itu keterlibatn mahasiswa dalam pembuatan konten kreatif yang diarahkan langsung oleh para dosen Ilmu Komunkasi melalui Mpu Kuturan (MK) TV. Partisipasi mahasiswa Prodi Ilmu Komunikasi dalam mengikuti berbagai ajang kompetisi literasi digital dan konten kreator sekaligus ikut memenangkan kegiatan tersebut. Memberikan ruang dialog pada mahasiswa sekaligus konten kreator dalam sharing knowledge dan skill sebagai bagian dari proses kreatif. Pemberdayaan-pemberdayaan literasi informasi dan digital di atas secara tidak langsung membangun sistem antihoax bagi mahasiswa karena mereka dituntut untuk berfikir kreatif, kritis, dan terus belajar. 
Jurnal IImu Komunikasi UHO : Jurnal Penelitian Kajian IImu Komunikasi dan Informasi.

Volume 6, No. 4, Oktober 2021, hlm 417-438

\section{SIMPULAN}

Adapun simpulan dari penelitian ini yakni selama Pandemi Covid-19 berlangsung mahasiswa Prodi Ilmu Komunikasi STAHN Mpu Kuturan Singaraja menjadikan media sosial dan media mainstream sebagai rujukan informasi untuk mengakses informasi. Media sosial dan media mainstream sangat mendominasi pengaruh terhadap mahasiswa dalam memberikan pandangan dan sikap terkait perkembangan Covid-19 termasuk potensi berita bohong atau hoaks yang tersebar. Meskipun demikian, dengan tingkat literasi digital yang baik, iklim akademik yang menunjang serta daya dukung lingkungan yang cukup produktif, mendorong mahasiswa berkesempatan untuk belajar dan berkesempatan mengasah skill digital dan terlibat dalam berbagai kegiatan literasi di kampus.

Sedangkan Persepsi mahasiswa menyikapi infodemik selama pandemi yakni mahasiswa terjebak dalam pusaran konspirasi, rumor dan stigma; menilai pengobatan terhadap Covid-19 masih simpan siur; panik dan stres akibat infodemik; media mainstream dinilai memperkeruh situasi pandemi; sentimen negatif dengan aparat negara; pesimis kinerja Pemerintah tuntaskan Pandemi Covid-19; dan tumbuhnya semangat solidaritas sosial saat krisis. 


\section{DAFTAR PUSTAKA}

Ardi, K., (2020). Infodemik di Saat Pandemi. https://himpsi.or.id/blog/materi-edukasi-covid19-5/post/infodemik-di-saat-pandemi-124. Diakses pada 11 Januari 2021

Arif, Ahmad. (2020), 14 Agustus. Kompas.id. Informasi Keliru tentang Covid-19 Mematikan. https://kompas.id/baca/humaniora/ilmu-pengetahuan-teknologi/2020/08/14/informasikeliru-tentang-covid-19-mematikan/ (online) Diakses pada 10 Januari 2021

Baran, S.J. \& Davis, D.K. (2009). Mass Communication Theory Foundation, Ferment and Future (5th eds). Boston: Wadsworth.

Baron, R. A., \& Byrne, D. (2003). Social Psychology. USA: Pearson Education Inc.

Baudrillard, J. (1994). Simulacra and simulation. Ann Arbor: University of Michigan Press.

Bawden, D. 2001. Information and Digital Literacies: a review of concepts. Journalof documentation.

Bungin, B. (2009). Sosiologi Komunikasi. Jakarta: Prenada Media

Bungin, Burhan. (2015). Penelitian Kualitatif: Komunikasi, Ekonomi, Kebijakan public, dan Ilmu Sosial Lainnya. Jakarta: Prenanda Media Group

Effendy, Onong Uchjana. (2005). Ilmu Komunikasi Teori dan Praktek, Bandung: Remaja Rosdakarya.

Gelgel, N, M, R, A., Ginting, R, T., Apriani, K, D., (2020). Kolaborasi, Riset, Dan Volunterisme Membangun Resiliensi Dalam Gejolak Pandemi dalam Universitas Udayana Melawan Disinfodemic Melalui Kelas Literasi Antihoaks

COVID-19 "Belajar Sembari Menyebar Berita Baik. MAFINDO: Jakarta Selatan

Gazendam, A., et al. (2020). "The 'Infodemic' of Journal Publication Associated with the Novel Coronavirus Disease". The Journal of Bone \& Joint Surgery, 102-A(13), July 1. DOI: $10.2106 / J B J S .20 .00610$

Gilster, P. (1997). Digital literacy, New York: Wiley

Gramsci, Antonio, (2013). Catatan-Catatan dari Penjara, Yogyakarta, Pustaka Pelajar.

Istiyanto, S. Bekti. (2015). Telepon Genggam dan Perubahan Sosial. Jakarta: Jurnal Komunikasi Ikatan Sarjana Komunikasi Indonesia (ISKI): Volume 2 No 2 Edisi JuliDesember 2015. ISSN 0853-4470

Jumrana. (2021). Pemberdayaan Literasi Digital dalam Membangun Sistem Antihoaks (135137. Kolaborasi, riset, dan volunterisme Membangun Resiliensi dalam Gejolak Pandemi. Jakarta Selatan: Mafinfo

Katz, E., Gurevitch, M., \& Haas, H. (1973). On the Use of the Mass Media for Important Things. American Sociological Review 38(2), 164-181.

Kurnia, N., Nurhajati, L., Astutu, S., I.2020. Kolaborasi Lawan (Hoaks) Covid-19: Kampanye, Riset dan Pengalaman Japelidi di Tengah Pandemi. Yogyakarta: Japelidi, Program Studi Magister Ilmu Komunikasi UGM.

Mas'udi, W., Winanti, P, S. (2020). Tata Kelola Penanganan Covid-19: Kajian Awal. Yogyakarta: Gadjah Mada Yogyakarta Press.

Meike dan Young. 2012. Hubungan Intensitas Mengakses Sosial Media terhadap Perilaku Belajar Mata Pelajaran Produktif pada Siswa Kelas XI Jasa Boga di SMK N 3 Klaten. Dalam Yuzi Akbari Vindita Riyanti (2016). Skripsi. Yogyakarta: Pendidikan Teknik Boga FT Universitas Negeri Yogyakarta.

Mulyana, Deddy. (2002) Ilmu Komunikasi Suatu Pengantar, Bandung: Remaja Rosdakarya. Nasrullah, Rulli. (2014). Teori dan Riset Media Siber (Cybermedia). Jakarta : Kencana Prenadamedia Group.

Nasrullah, R. (2015). Media sosial (perspektif komunikasi, budaya, dan sosioteknologi). Jakarta: Simbiosa Rekatama Media 
Jurnal IImu Komunikasi UHO : Jurnal Penelitian Kajian IImu Komunikasi dan Informasi.

Volume 6, No. 4, Oktober 2021, hlm 417-438

Ohanian, R. (1991). The impact of celebrity spokespersons perceived image on consumer intention to purchase. Journal of advertising research

Palmgreen, Philip. (2001) Communication Research Measures: A Sourcebook. The Guilford Press,.

Perangin-angin, L.L.K., (2021)Infodemi di Ruang Komunitas Virtual: Aktualisasi Diri vs Akurasi (48-49). Kolaborasi, riset, dan volunterisme Membangun Resiliensi dalam Gejolak Pandemi. Jakarta Selatan: Mafinfo

Posetti, J., and Bontcheva, K., (2020). Disinfocemic: Deciphering COVID-19 disinformation. Policy brief (1) : UNESCO

Pratiwi Agustini ( 2021, Mei 3). Kominfo Catat 1.733 Hoaks Covid-19 dan Vaksin. Diakses pada 15 Juli 2021. dari https://aptika.kominfo.go.id/2021/05/kominfo-catat-1-733hoaks-covid-19-dan-vaksin/

Rakhmat, Jalaluddin. Psikologi Komunikasi, Bandung: Remaja Rosdakarya, 1984 dan 2001.

: https://www.kompas.id/baca/ilmu-pengetahuan-teknologi/2021/07/26/kasus-covid-19-dijakarta-menurun-namun-meluas-di-indonesia

Sendja, Wied, Ganes, Zaldy \& Teguh Santosa. Komunikasi dan Budaya. Jakarta: Jurnal UI, 2001.

Siswati, E., (2017). Anotomi Teori Hegemoni Antonio Gramci. Jurnal Translitera. Edisi 5

Soewartoyo dan Potntas Sinaga. 2014. Teknik dan Praktik Pengumpulan Data Lapangan. Jakarta: Pusbindiklat Peneliti LIPI

Suryani, C., Hidayah, N., Safitri, F.N., (2020) .Kolaborasi, Riset, dan Volunterisme: Membangun Resiliensi dalam Gejolak Pandemi. Jakarta Selatan: Mafindo

Sugiyono. 2010. Metodelogi Penelitian pendekatan Kuantitatif, Kualitatif dan R\&D. Bandung: Alfabeta

Susanti, P.F., (2021) Disensus dan Disinformasi: Tantangan Menghadapi Pandemi COVID19 di Negara Demokrasi (24). Kolaborasi, riset, dan volunterisme Membangun Resiliensi dalam Gejolak Pandemi. Jakarta Selatan: Mafinfo

Suriastini. W., Sikoki, B., Listiono (2020, Juli 21 ). Gangguan Kesehatan Mental Meningkat Tajam di Masa Pandemi COVID-19? diakses pada 12 Juli 2021 dari https://www.surveymeter.org/id/node/576

Sutrisna, I.P.G., (2020). Gerakan Literasi Digital Pada Masa Pandemi Covid-19. Jurnal Stilistika. Volume 8 nomor 2.

Mohsin, Anto. (2020). theconversation.com. Mengapa Infodemi Covid19 Begitu Cepat Menyebar Lewat Media Sosial ?. (Online) https://theconversation.com/mengapainfodemi-covid-19-begitu-cepat-menyebar-lewat-media-sosial-137715 diakses 9 Januari 20201

Morissan. (2014). Teori Komunikasi Individu Hingga Massa. Jakarta : Kencana

Tim Penyusun. (2008). Kamus Besar Bahasa Indonesia Pusat Bahasa. Jakarta: Gramedia

Wasdiana. M.D., Arifiyana. I.P., (2021). Penerapan Keterampilan Literasi Penerapan Keterampilan Literasi Informasi dalam Melawan Informasi Hoaks COVID-19 di Media Sosial (115-116). Kolaborasi, riset, dan volunterisme Membangun Resiliensi dalam Gejolak Pandemi. Jakarta Selatan: Mafinfo

Widiantara, I Komang Agus. (2020). Infodemik Covid-19: Momentum Membangun Kepercayaan Publik Terhadap Media Mainstream. Jurnal Danapati : Vol.1 No 1 Halaman 68.

WHO. (2020b). Technical Focus: Risk communication and community engagement. Geneva: World Health Organization. Diakses dari https://www.who.int/docs/defaultsource/coronaviruse/situationreports/20200202-sitrep-13-ncovv3.pdf?sfvrsn=195f4010_ 
Jurnal IImu Komunikasi UHO : Jurnal Penelitian Kajian IImu Komunikasi dan Informasi.

Volume 6, No. 4, Oktober 2021, hlm 417-438

Van Dijk, J. (2013). The Culture of Connectivity: A critical History of Social Media. UK: Oxford University Press. 